\title{
ASSESSMENT OF QUALITY OF NEW Rf INBRED LINES RESISTANT TO BROOMRAPE RASE E (Orobanche cumana Wallr.) DEVELOPED FROM H. deserticola BY INTERSPECIFIC HYBRIDIZATION
}

\author{
Hladni, N. ${ }^{*}$, Jocić, S. ${ }^{1}$, Miklič, V. ${ }^{1}$, Sakač, Z. ${ }^{1}$, Škorić, D. ${ }^{2}$ \\ ${ }^{1}$ Institute of Field and Vegetable Crops (IFVC), Oil Crops Department, \\ Maksima Gorkog 30, 21000 Novi Sad, Serbia \\ ${ }^{2}$ Serbian Academy of Science and Arts, Branch in Novi Sad, Nikole Pašića 6, \\ 21000 Novi Sad, Serbia
}

Received: July 25, 2010

Accepted: November 15, 2010

\begin{abstract}
SUMMARY
Broomrape (Orobanche cumana Wallr.) presents a serious problem in sunflower production in a number of countries. The population of broomrape has been stable in Serbia for a long period of time, but the racial composition has changed in recent years, with race $\mathrm{E}$ being predominant in the regions of north Bačka and Banat. Cultivated sunflower is genetically narrow and deficient in many desirable genes. Sources of resistance genes to broomrape can be found in a number of wild sunflower species. New $7 R f$ inbred lines (RHA-D1, RHA-D-2, RHA-D-5, RHA-D-6, RHA-D-7, RHA-D-8, RHA-D-9) were produced from interspecies population originating from $H$. deserticola (DES-1474-1) in IFVC. The inbreeding of the selected plants from interspecific populations started in $1995\left(\mathrm{~S}_{1}\right)$. The first screening of sunflower $R f$ lines for broomrape resistance was done in a glasshouse in $1999\left(\mathrm{~S}_{5}\right)$. The seed from the resistant plants was tested in infested fields, in the area of S. Miletić and B. Topola during $2000\left(\mathrm{~S}_{6}\right)$. Selection of resistant plants was checked from $2001\left(\mathrm{~S}_{7}\right)$ to $2003\left(\mathrm{~S}_{9}\right)$. The same procedure was conducted in Pačir from $2004\left(\mathrm{~S}_{10}\right)$ to $2008\left(\mathrm{~S}_{14}\right)$ and in the area of Lipar in $2009\left(\mathrm{~S}_{15}\right)$. Experimental hybrids were produced by crossing new $R f$ lines developed from interspecific population (DES-1474-1) resistant to broomrape race $\mathrm{E}$ with $\mathrm{cms}$ female lines susceptible to broomrape. The resistance of new 28 experimental hybrids to broomrape was checked on locations in Serbia (Pačir 2006, 2007, 2008) and at the location (Lipar 2009) with three controls: hybrid Bačvanin, resistant to race $\mathrm{E}$, hybrid NS-H-111 resistant to race A, B, C, D, susceptible to E race and line AD66 susceptible to all broomrape races. The resistance of the same hybrids was also tested at a location in Romania (Baragan, Braila) in 2008. All examined hybrids were resistant to broomrape race $\mathrm{E}$ on all locations.
\end{abstract}

Key words: sunflower, interspecific hybridization, resistance, broomrape, Orobanche cumana Wallr.

* Corresponding author: Phone: +381 214898 411; Fax: +380 219413 833;

e-mail: nada.hladni@ifvcns.ns.ac.rs 


\section{INTRODUCTION}

Broomrape is one of the largest problems in sunflower production. It reduces sunflower seed yield and negatively affects other sunflower traits (Demirci and Kaya, 2009). Different pathogenic races of Orobanche cumana Wallr. are known to exist in various regions of Europe and in the Southeastern Mediterranean, where the climate is favorable for this parasite (Virány, 2008). The virulence of the parasite populations of broomrape has changed over years, slowly at first, then rapidly in Eastern Europe, Turkey and Spain. The parasite is becoming more and more dangerous for the sunflower crop (Pacureanu et al., 2008). Broomrape resistance is poorly understood and new races of the parasite are evolving rapidly and overcoming the resistance of newly introduced sunflower hybrids (Virány, 2008). It can significantly reduce seed and oil yield, weight of 1000 seeds, seed oil content, plant height and head diameter in sunflower production (Kaya et al., 2004). Breeding strategies for incorporating broomrape resistance into sunflower commercial hybrids have been nearly exclusively based on single race-specific dominant genes, which are considered by seed companies as an ideal source of resistance for singlecross hybrid breeding, as they only need to be incorporated into one of the parents (Fernández-Martínez et al., 2008). The resistance to races is controlled by single dominant genes (Or). With the increase of the sunflower covered areas in the world, new races of broomrape have also developed. Until a few years ago among the sunflower broomrape populations only 5 physiological races (A, B, C, D and E) and five sunflower dominant genes $\left(\mathrm{Or}_{1}, \mathrm{Or}_{2}, \mathrm{Or}_{3}, \mathrm{Or}_{4}\right.$ and $\left.\mathrm{Or}_{5}\right)$ conferring the resistance towards broomrape races were known. Recently there has been a sudden change in race composition. New races have appeared: race $\mathrm{F}$ in Romania, Bulgaria, Spain and Turkey. The new broomrape races cannot be controlled by $\mathrm{Or}_{5}$ gene (race E). The changes in the broomrape population and the appearance of new races represent a crucial point in sunflower breeding, forcing the breeders to continually test the breeding material against new broomrape races while creating differential lines (Hladni et al., 2009).

Sources of resistance to the recent virulent races $\mathrm{E}$ and $\mathrm{F}$ have been located in cultivated germplasm (Gulya et al., 1994; Fernández-Martínez et al., 2000), in contrast, a high level of resistance to races E, F and G has been found in the evaluation of wild Helianthus species, particularly perennials (Škorić, 1988; Ruso et al., 1996; Fernández-Martínez et al., 2000), revealing that wild Helianthus species constitute a major pool of genes for resistance to the new virulent races of broomrape. Different ways for controlling parasite attacks were tested (different methods of soil cultivation, herbicides use, biological agents, etc.), which gave no viable practical results. Till now the broomrape problem was mainly solved by genetic means, by finding new resistance sources and developing new sunflower material resistant to the new parasite races (Christov et al., 2009). Epiphytotic occurrence of broomrape was observed in Serbia for the first time in 1951. During a longer period of time the broomrape population in Serbia was stable. Race B is dominant in the South of the 
Vojvodina Province and race $\mathrm{E}$ in the North (Dedić et al., 2009). Race $\mathrm{E}$ has expanded to the Bačka and Banat regions and is slowly starting to become a big problem in sunflower production. In 2008, infected areas were found in Bor County (two sunflower plots) near the state border with Romania and Bulgaria (Dedić et al., 2009; Maširević et al., 2009). Continual monitoring of the broomrape population in Serbia is very important due to changes in race composition and evolution of new more virulent races in neighbouring countries and also because climate changes are favorable for expansion of Orobanche species to large areas Maširević et al. (2009). The sunflower breeding program at the Institute of Field and Vegetable Crops has been directed towards creating lines and hybrids which will be resistant to new races of broomrape using interspecific hybridization. In this investigation several interspecific populations with $H$. deserticola were initially used for the production of $R f$ male inbred lines resistant to drought. When creating hybrids resistant to drought and high temperatures, it is important to use wild species of the genus Helianthus, which inhabit desert and semi-desert areas (Fick and Miller, 1997; Škorić, 2009). Several agronomicaly important traits of new $R f$ inbred lines and their hybrids were evaluated and are discussed in the paper. Unexpectedly, the resistance to broomrape race $\mathrm{E}$ was consistent on all examined locations in Serbia (Pačir 2006, 2007, 2008 and Lipar 2009) and at a location in Romania (Baragan, Braila 2008). This result indicates that some inbred lines developed from interspecific populations originating from $\mathrm{H}$. deserticola are resistant to broomrape and can be used for the production of new resistant sunflower hybrids.

\section{MATERIAL AND METHOD}

New $R f$ inbred lines (RHA-D-1, RHA-D-2, RHA-D-5, RHA-D-6, RHA-D-7, RHA-D8, RHA-D-9) were produced from an interspecific population originating from $H$. deserticola in Institute of Field and Vegetable Crops (IFVC). Initially, the plants were selected from the interspecific population DES-1474-1, 2, 3 provided by Dr Gerald Seiler (USDA-ARS, Fargo ND, USA) originating from $H$. deserticola. The inbreeding of selected plants from interspecific populations started in $1995\left(\mathrm{~S}_{1}\right)$. The first screening of sunflower $R f$ lines for broomrape resistance was done in the glasshouse in $1999\left(\mathrm{~S}_{5}\right)$. The seed from the resistant plants was tested in infested fields, in the area of S. Miletić and B. Topola during $2000\left(\mathrm{~S}_{6}\right)$. Selection of resistant plants was continued in $2001\left(\mathrm{~S}_{7}\right), 2002\left(\mathrm{~S}_{8}\right)$ and $2003\left(\mathrm{~S}_{9}\right)$. The same procedure was conducted in Pačir from $2004\left(\mathrm{~S}_{10}\right)$ to $2008\left(\mathrm{~S}_{14}\right)$ and Lipar $2009\left(\mathrm{~S}_{15}\right)$ which resulted in 7 resistant restorer inbred lines. In all locations lines were sown in 3 rows ( 12 plants per row), of which only the plants in the middle one were evaluated. In order to measure the morphophysiological traits of resistant lines the experiment was set at an experimental field of the IFVC at Rimski Šančevi, in a randomized complete block system with three replications during 2008/2009. The basic sample for the analysis of the examined trait contained 30 plants (10 plants per replication) sampled from the middle row of each block. The plant height (PH) and head diameter (HD) were measured $(\mathrm{cm})$ in the field at the stage of physiological maturity. The analysis of oil content (SOC) in seed was carried out non-destruc- 
tively on a nuclear magnetic resonance (NMR) analyzer. Seed protein content (SPC) was determined by the Kjeldahl method. Both analyses were performed at the chemical laboratory of the Institute's Oil Crops Department. On a random sample of completely pure and air dried seed the weight of 1000 seeds (M1000S) was determined (g).

The resistance of 28 new experimental hybrids to broomrape was tested on locations in Serbia (Pačir) during three years (2006, 2007 and 2008) and (Lipar) in 2009. In Romania new experimental hybrids to broomrape were tested in (Baragan, Braila) during 2008. These hybrids were produced by crossing female inbred lines (Ha-26PR-A, PH-BC ${ }_{2}$-92-A, Ha-98-A and HA-1200A) resistant to race D but susceptible to race $\mathrm{E}$ and new $R f$ inbred lines (RHA-D-1, RHA-D-2, RHA-D-5, RHA-D-6, RHA-D-7, RHA-D-8, RHA-D-9), developed from interspecies population originating from $H$. deserticola, and resistant to broomrape race E. Control sunflower genotypes used in Serbia were the line AD-66 susceptible to all broomrape race, hybrid NS-H-111 resistant to race $(A, B, C, D)$ susceptible to $E$ race and the hybrid Bačvanin, which is resistant to the broomrape race $\mathrm{E}$ (contains gene $\mathrm{Or}_{5}$ ). The basic sample for the analysis of the examined trait contained 40 plants (20 plants per replication) sampled from the middle row of each block. In the small plot trials 28 , NS-experimental hybrid was set up in 2008 and 2009 on the location of Rimski Šančevi, Serbia in a randomized complete block system with three replications, with the basic field size of $28 \mathrm{~m}^{2}$ ( 4 rows). The hybrids were evaluated for PH, HD, SY, SOC and OY. The seed yield (SY) was normalized to $11 \%$ of seed moisture content. Oil yield (OY) was calculated from the seed yield and oil content. The highyielding hybrids Baća and Šumadinac (resistant to broomrape (race E)) and Sremac (non-resistant to broomrape) were used as standards. The determination of mean values and Two-Way ANOVA without replication was performed according to Hadživuković (1991).

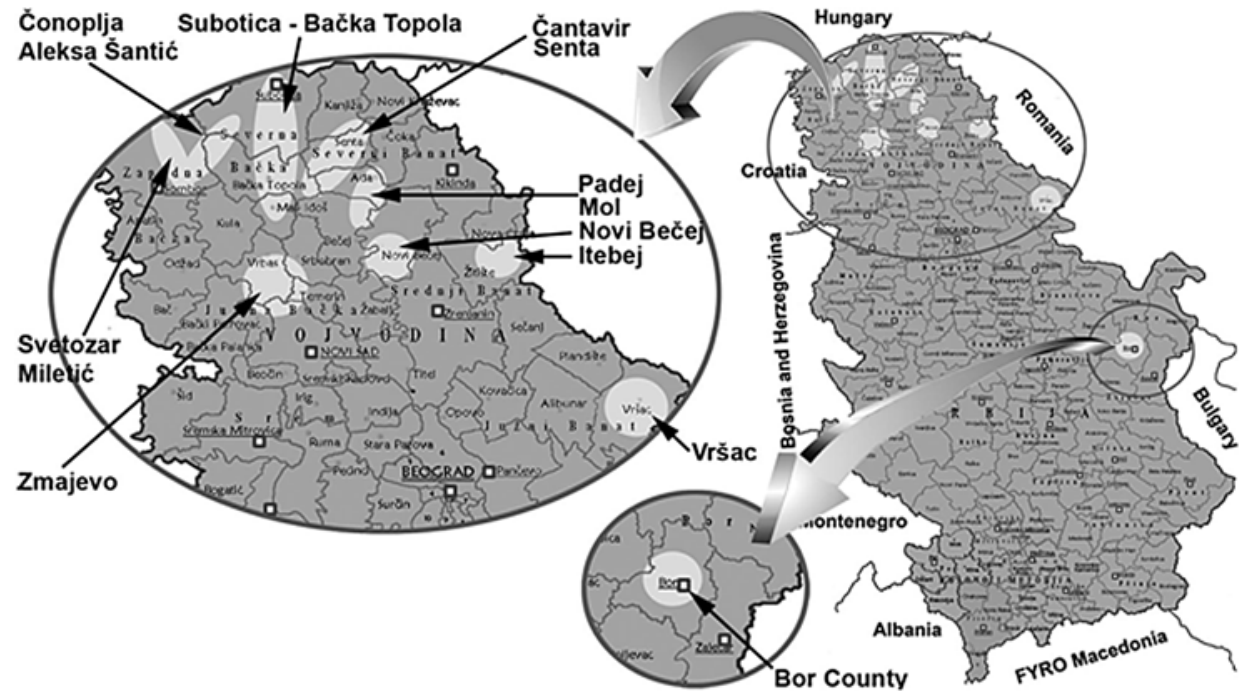

Figure 1: The main areas of broomrape infestation in the sunflower crop in Serbia. 


\section{RESULTS AND DISCUSSION}

Broomrape is present in Province Vojvodina as the main sunflower production region in Serbia. Main hazardous areas are sunflower fields on the route Subotica B. Topola, with a tendency of spreading toward Senta and Cantavir, and then to the south. A less intensive attack has also been noticed in Banat around Padej, Itebej and Vršac. In 2008, infected areas were found in Bor County (two sunflower plots) near the state border with Romania and Bulgaria (Figure 1). The continuous problem with broomrape spread asked for continuous research work in the field, searching for new sunflower materials resistant to the new races. Till now the broomrape problem was mainly solved by genetic means, by finding new resistance sources and developing new sunflower material resistant to the new parasite races. $H$. deserticola can be used for drought tolerance as well as oil concentration and quality improvement (Seiler, 2007). Breeding of sunflower inbred lines originating from interspecific populations DES-1474-1, DES-1474-2 and DES-1474-3, in order to implement drought tolerance, started in 1994 at the IFVC. Apart from the analysis of important agronomic traits new restorer inbred lines were tested for resistance to broomrape. A continued work on the testing of restorer inbred lines was conducted from 1995 to 2003, which resulted in 7 restorer inbred lines originating from interspecific population DES-1474-1, resistant to broomrape race E (Hladni et al., 2009). The resistance of new lines was checked on location Pačir from 20042008 and location Lipar in 2009 with three controls: AD-66 line susceptible to all broomrape races, hybrid NS-H-111 resistant to race $\mathrm{A}, \mathrm{B}, \mathrm{C}, \mathrm{D}$ and hybrid Bačvanin-resistant to broomrape race $\mathrm{E}$ (Table 1).

Table 1: $R f$ inbred lines resistant to broomrape race $\mathrm{E}$ created from interspecies populations originating from $H$. deserticola and their values of plant height, head diameter, seed oil content, seed protein content and mass of 1000 seed in 2008/2009.

\begin{tabular}{llcccccccc}
\hline & Population & Pačir & Lipar & Traits & PH & HD & SOC & SPC & $1000 \mathrm{sm}$ \\
& DES-1474-1 & 04-08 & 09 & & & & & \\
& $R f$ inbred lines & $\mathrm{S}_{10}-\mathrm{S}_{14}$ & $\mathrm{~S}_{15}$ & & $\mathrm{~cm}$ & $\mathrm{~cm}$ & $\%$ & $\%$ & $\mathrm{~g}$ \\
\hline 1 & RHA-D-1 & $\mathrm{R}$ & $\mathrm{R}$ & & 150 & 12.0 & 40.5 & 20.1 & 41.0 \\
2 & RHA-D-2 & $\mathrm{R}$ & $\mathrm{R}$ & & 149 & 12.5 & 39.2 & 20.7 & 47.2 \\
3 & RHA-D-5 & $\mathrm{R}$ & $\mathrm{R}$ & & 160 & 12.8 & 40.1 & 21.2 & 48.5 \\
4 & RHA-D-6 & $\mathrm{R}$ & $\mathrm{R}$ & & 140 & 13.5 & 44.2 & 18.8 & 58.7 \\
5 & RHA-D-7 & $\mathrm{R}$ & $\mathrm{R}$ & & 144 & 12.7 & 46.3 & 20.4 & 50.5 \\
6 & RHA-D-8 & $\mathrm{R}$ & $\mathrm{R}$ & & 172 & 14.2 & 44.1 & 21.1 & 51.5 \\
7 & RHA-D-9 & $\mathrm{R}$ & $\mathrm{R}$ & & 152 & 14.5 & 38.3 & 22.0 & 43.8 \\
\hline control & AD-66 & $\mathrm{S}$ & $\mathrm{S}$ & LSD 0.05 & 8 & 0.3 & 0.9 & 0.8 & 1.5 \\
control & NS-H-111 & $\mathrm{S}$ & $\mathrm{S}$ & LSD 0.01 & 13 & 0.5 & 1.4 & 1.2 & 2.4 \\
control & Bačvanin & $\mathrm{R}$ & $\mathrm{R}$ & & & & & & \\
\hline
\end{tabular}

(R) + broomrape absent; (S) - broomrape present on every plant; PH-plant height; HD-head diameter; SOC-seed oil content; SPC-seed protein content; 1000sm-mass of 1000 seed 
Table 2: Testing of NS sunflower hybrids in field conditions on parcels infected by broomrape on the locations of Pačir (P) from 2006-2008, Lipar (L) from 2009 and Braila (B) from 2008 and mean values of morphophysiological traits of the hybrids tested during 2008/2009 on the location of Rimski Šančevi (RŠ).

\begin{tabular}{|c|c|c|c|c|c|c|c|c|c|c|c|c|}
\hline & \multirow{3}{*}{$\begin{array}{l}\mathrm{F}_{1} \text { hy- } \\
\text { brids }\end{array}$} & \multirow{3}{*}{ cms } & \multirow{3}{*}{$\mathrm{Rf}$} & \multirow{2}{*}{$\mathrm{P}$} & \multirow{2}{*}{ L } & \multirow{2}{*}{ B } & \multirow{3}{*}{ Traits } & \multicolumn{5}{|c|}{ RS } \\
\hline & & & & & & & & $\mathrm{PH}$ & HD & SOC & SY & OY \\
\hline & & & & $06-08$ & 09 & 08 & & $\mathrm{~cm}$ & $\mathrm{~cm}$ & $\%$ & $\mathrm{t} \mathrm{ha}^{-1}$ & $\mathrm{tha}^{-1}$ \\
\hline 1 & $\mathrm{NS}-\mathrm{H}-1$ & Ha-26PR-A & RHA-D-1 & $\mathrm{R}$ & $\mathrm{R}$ & $\mathrm{R}$ & & 179 & 20.5 & 47.1 & 3.71 & 1.75 \\
\hline 2 & NS-H-2 & & RHA-D-2 & $\mathrm{R}$ & $\mathrm{R}$ & $\mathrm{R}$ & & 177 & 20.5 & 47.1 & 3.81 & 1.79 \\
\hline 3 & NS-H-3 & & RHA-D-5 & $\mathrm{R}$ & $\mathrm{R}$ & $\mathrm{R}$ & & 195 & 21.5 & 48.1 & 3.64 & 1.75 \\
\hline 4 & NS-H-4 & & RHA-D-6 & $\mathrm{R}$ & $\mathrm{R}$ & $\mathrm{R}$ & & 171 & 21.0 & 47.4 & 3.73 & 1.76 \\
\hline 5 & NS-H-5 & & RHA-D-7 & $\mathrm{R}$ & $\mathrm{R}$ & $\mathrm{R}$ & & 169 & 22.0 & 48.1 & 4.00 & 1.92 \\
\hline 6 & NS-H-6 & & RHA-D-8 & $\mathrm{R}$ & $\mathrm{R}$ & $\mathrm{R}$ & & 205 & 23.0 & 48.2 & 4.19 & 2.02 \\
\hline 7 & NS-H-7 & & RHA-D-9 & $\mathrm{R}$ & $\mathrm{R}$ & $\mathrm{R}$ & & 185 & 21.0 & 48.4 & 4.04 & 1.96 \\
\hline 8 & NS-H-8 & $\mathrm{PH}-\mathrm{BC}_{2}-92-\mathrm{A}$ & RHA-D-1 & $\mathrm{R}$ & $\mathrm{R}$ & $\mathrm{R}$ & & 177 & 20.0 & 47.3 & 3.71 & 1.76 \\
\hline 9 & NS-H-9 & & RHA-D-2 & $\mathrm{R}$ & $\mathrm{R}$ & $\mathrm{R}$ & & 175 & 20.0 & 48.4 & 3.76 & 1.82 \\
\hline 10 & $\mathrm{NS}-\mathrm{H}-10$ & & RHA-D-5 & $\mathrm{R}$ & $\mathrm{R}$ & $\mathrm{R}$ & & 185 & 21.0 & 48.2 & 3.73 & 1.80 \\
\hline 11 & $\mathrm{NS}-\mathrm{H}-11$ & & RHA-D-6 & $\mathrm{R}$ & $\mathrm{R}$ & $\mathrm{R}$ & & 175 & 20.0 & 47.6 & 3.55 & 1.69 \\
\hline 12 & $\mathrm{NS}-\mathrm{H}-12$ & & RHA-D-7 & $\mathrm{R}$ & $\mathrm{R}$ & $R$ & & 165 & 23.1 & 48.2 & 3.56 & 1.71 \\
\hline 13 & $\mathrm{NS}-\mathrm{H}-13$ & & RHA-D-8 & $\mathrm{R}$ & $\mathrm{R}$ & $\mathrm{R}$ & & 200 & 21 & 48.4 & 3.96 & 1.91 \\
\hline 14 & NS-H-14 & & RHA-D-9 & $\mathrm{R}$ & $\mathrm{R}$ & $\mathrm{R}$ & & 175 & 21.5 & 48.5 & 3.96 & 1.92 \\
\hline 15 & NS-H-15 & На-98-А & RHA-D-1 & $\mathrm{R}$ & $\mathrm{R}$ & $\mathrm{R}$ & & 193 & 21.0 & 49.6 & 3.98 & 1.97 \\
\hline 16 & NS-H-16 & & RHA-D-2 & $\mathrm{R}$ & $\mathrm{R}$ & $\mathrm{R}$ & & 192 & 22.0 & 50.1 & 4.17 & 2.09 \\
\hline 17 & $\mathrm{NS}-\mathrm{H}-17$ & & RHA-D-5 & $\mathrm{R}$ & $\mathrm{R}$ & $\mathrm{R}$ & & 193 & 22.0 & 49.0 & 3.53 & 1.73 \\
\hline 18 & NS-H-18 & & RHA-D-6 & $\mathrm{R}$ & $\mathrm{R}$ & $\mathrm{R}$ & & 181 & 22.0 & 48.4 & 4.10 & 1.99 \\
\hline 19 & NS-H-19 & & RHA-D-7 & $\mathrm{R}$ & $\mathrm{R}$ & $\mathrm{R}$ & & 183 & 23.0 & 49.1 & 4.15 & 2.04 \\
\hline 20 & NS-H-20 & & RHA-D-8 & $\mathrm{R}$ & $\mathrm{R}$ & R & & 200 & 23.0 & 48.8 & 4.13 & 2.01 \\
\hline 21 & NS-H-21 & & RHA-D-9 & $\mathrm{R}$ & $\mathrm{R}$ & $\mathrm{R}$ & & 195 & 21.0 & 48.8 & 3.99 & 1.95 \\
\hline 22 & NS-H-22 & $\mathrm{HA}-1200 \mathrm{~A}$ & RHA-D-1 & $\mathrm{R}$ & $R$ & $\mathrm{R}$ & & 191 & 19.0 & 46.6 & 3.45 & 1.61 \\
\hline 23 & NS-H-23 & & RHA-D-2 & $\mathrm{R}$ & $\mathrm{R}$ & $\mathrm{R}$ & & 190 & 20.0 & 46.9 & 3.55 & 1.66 \\
\hline 24 & NS-H-24 & & RHA-D-5 & $\mathrm{R}$ & $\mathrm{R}$ & $\mathrm{R}$ & & 193 & 19.5 & 46.9 & 3.59 & 1.68 \\
\hline 25 & NS-H-25 & & RHA-D-6 & $\mathrm{R}$ & $\mathrm{R}$ & $\mathrm{R}$ & & 183 & 20.0 & 46.4 & 3.70 & 1.72 \\
\hline 23 & NS-H-26 & & RHA-D-7 & $\mathrm{R}$ & $\mathrm{R}$ & $\mathrm{R}$ & & 181 & 20.5 & 48.1 & 3.90 & 1.87 \\
\hline 27 & NS-H-27 & & RHA-D-8 & $\mathrm{R}$ & $\mathrm{R}$ & $\mathrm{R}$ & & 205 & 22.0 & 48.0 & 3.88 & 1.86 \\
\hline \multirow[t]{9}{*}{28} & NS-H-28 & & RHA-D-9 & $\mathrm{R}$ & $\mathrm{R}$ & $\mathrm{R}$ & & 193 & 19.0 & 47.2 & 3.95 & 1.86 \\
\hline & & & & & & & standard & & & & & \\
\hline & & & & & & & Baća & 185 & 22.5 & 47.7 & 3.63 & 1.73 \\
\hline & control & AD-66 & & S & $\mathrm{S}$ & & Šumadinac & 170 & 23.5 & 47.9 & 3.81 & 1.82 \\
\hline & & & & & & & Sremac & 179 & 24.0 & 44.9 & 4.01 & 1.80 \\
\hline & control & NS-H-111 & & S & $\mathrm{S}$ & & & 185 & 23.0 & 48.4 & 3.52 & 1.70 \\
\hline & control & Bačvanin & & $\mathrm{R}$ & $\mathrm{R}$ & & & 180 & 23.0 & 48.0 & 3.65 & 1.75 \\
\hline & LSD & 0.05 & & & & & & 1.5 & 0.8 & 1.5 & 0.46 & 0.22 \\
\hline & LSD & 0.01 & & & & & & 2.0 & 1.0 & 1.9 & 0.62 & 0.30 \\
\hline
\end{tabular}

(R) - broomrape absent; (S) - broomrape present on every plant; PH-plant height; HD-head diameter; SOC-seed oil content; SY-seed yield; OY-oil yield. 
The new $R f$ lines studied differed significantly in the mean values of all the traits under investigation: PH varied from $140 \mathrm{~cm}$ (RHA-D-6) to $172 \mathrm{~cm}$ (RHA-D-8), HD ranged from $12.0 \mathrm{~cm}$ (RHA-D-1) to $14.5 \mathrm{~cm}$ (RHA-D-9), SOC varied from $38.3 \%$ (RHA-D-9) to $46.3 \%$ (RHA-D-7), SPC from 18.8\% (RHA-D-6) to $22.0 \%$ (RHA-D-9) and $1000 \mathrm{sm}$ from $41.0 \mathrm{~g}$ (RHA-D-1) to $58.7 \mathrm{~g}$ (RHA-D-6) (Table 1). The resistance of 28 new experimental hybrids to broomrape was confirmed on locations in Serbia (Pačir 2006-2008) and location (Lipar 2009) with three controls: hybrid Bačvanin, hybrid NS-H-111 and line AD-66. As the race F is present in Romania, the resistance of the same hybrids was also tested and confirmed there, at the location (Baragan, Braila, 2008) (Table 2). During 2008/2009 on the location of R. Šančevi morphophysiological traits of new experimental sunflower hybrids resistant to broomrape were examined. Significant differences were determined in the mean values for all the traits studied: PH from $165 \mathrm{~cm}$ (NS-H-12) to $205 \mathrm{~cm}$ (NS-H-6), HD $19.0 \mathrm{~cm}$ (NS-H-22) to $23.1 \mathrm{~cm}$ (NS-H-12), SY from $3.45 \mathrm{t} \mathrm{ha}^{-1}$ (NS-H-22) to $4.19 \mathrm{t}$ $\mathrm{ha}^{-1}$ (NS-H-6), SOC from 46.4\% (NS-H-25) to 50.1\% (NS-H-16) and OY from $1.61 \mathrm{t}$ $\mathrm{ha}^{-1}$ (NS-H-22) to $2.09 \mathrm{t} \mathrm{ha}^{-1}$ (NS-H-16) (Figures 2, 3 and 4). Ten new hybrids resistant to broomrape were significantly better in mean values of SOC in relation to SOC achieved with the control NS-H-111 (48.4\%) which were significantly better than all for standard hybrids (Table 2, Figure 3). On the basis of two year results for the agronomicaly most important traits such as SY, SOC and OY gained on the location of R. Šančevi during 2008/09, new five hybrids resistant to broomrape NS-H-6 (SY $4.19 \mathrm{t} \mathrm{ha}^{-1}$; SOC $48.2 \%$; OY $2.02 \mathrm{t} \mathrm{ha}^{-1}$ ), NS-H-16 (SY $4.17 \mathrm{t} \mathrm{ha}^{-1}$; SOC $50.1 \%$; OY $2.09 \mathrm{t} \mathrm{ha}^{-1}$ ), NS-H-19 (SY $4.15 \mathrm{t} \mathrm{ha}^{-1}$; SOC $49.1 \%$; OY $2.04 \mathrm{t} \mathrm{ha}^{-1}$ ), NS-H-20 (SY $4.13 \mathrm{t} \mathrm{ha}^{-1}$; SOC $48.8 \%$; OY $2.01 \mathrm{t} \mathrm{ha}^{-1}$ ), NS-H-18 (SY $4.10 \mathrm{t} \mathrm{ha}^{-1}$; SOC $48.4 \%$; OY $1.99 \mathrm{t} \mathrm{ha}^{-1}$ ) had significantly better SY in relation to the best standard, Sremac (SY $4.01 \mathrm{t} \mathrm{ha}^{-1}$ ) and SOC and OY in relation to the best standard Šumadinac (SOC 47.9\%; OY $1.82 \mathrm{t} \mathrm{ha}^{-1}$ ) (Table 2, Figures 2, 3 and 4).

Interspecific hybridization or the discovery of desirable genes in the wild species of the genus Helianthus and their incorporation into cultivated sunflower genotypes, which is a valuable source of resistance genes, holds a special place in sunflower breeding and makes room for the discovery of the resistances towards different broomrape races, which has been shown in this paper. New sources of resistance to broomrape have often been searched for in wild species, with focus on H. tuberosus (Jan et al., 2002). Most of the NS hybrids resistant to broomrape produced so far were based on interspecific populations with $H$. tuberosus, among them hybrid Bačvanin, used as a control in our research. Results on the resistance of other sunflower wild populations are scarce. Seiler (1994) showed that interspecific lines derived from $H$. anomalus, $H$. argophyllus and $H$. deserticola showed some level of resistance against broomrape race SE-192. Ruso et al. (1996) defined only three interspecific populations (ANO-1509-2-2, ARG-420-1-2 and DES-1474-12 derived from $H$. anomalus, $H$. argophyllus and $H$. deserticola, respectively) that were partially resistant to broomrape race SE-193. It is known that among each 


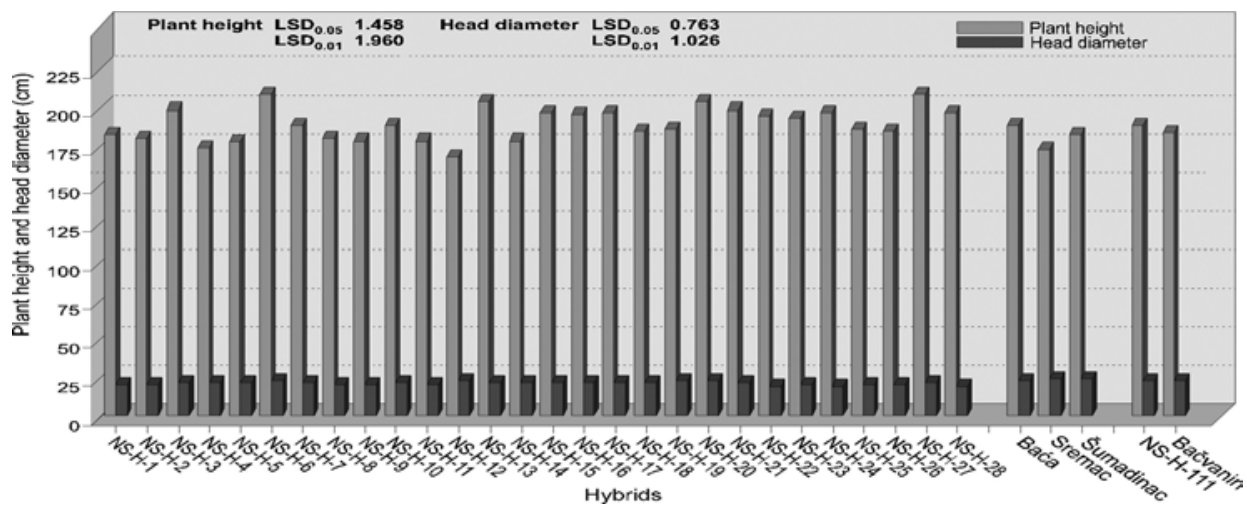

Figure 2: The mean values of morphophysiological traits (plant height and head diameter) of the new NS sunflower hybrids, resistant to broomrape race E, tested during $2008 / 2009$ on the location of Rimski Šančevi.

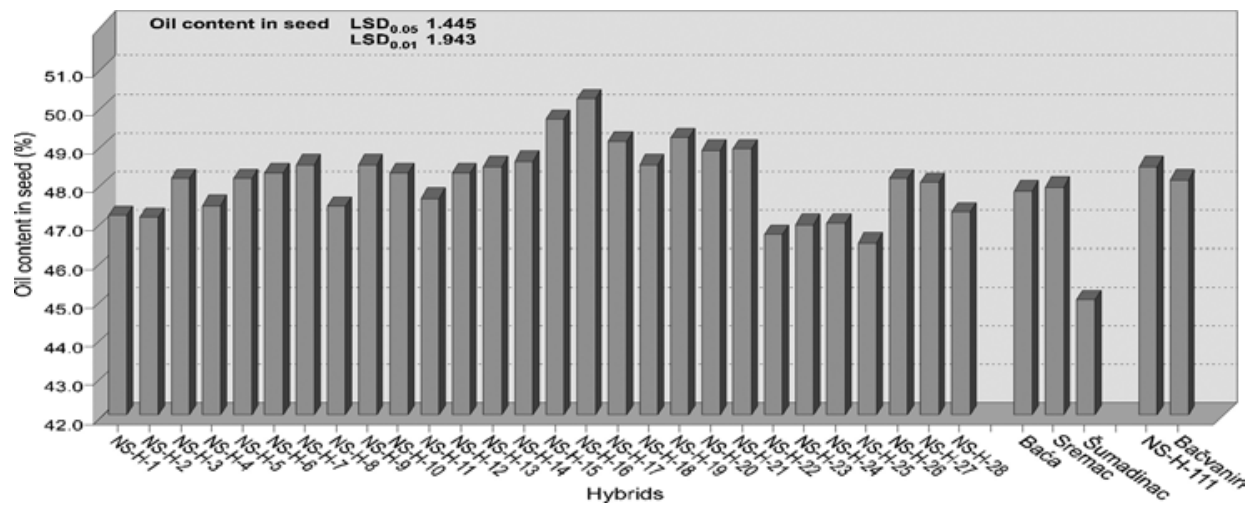

Figure 3: The mean values of morphophysiological traits (seed oil content) of the new NS sunflower hybrids, resistant to broomrape race E, tested during 2008/2009 on the location of Rimski Šančevi.

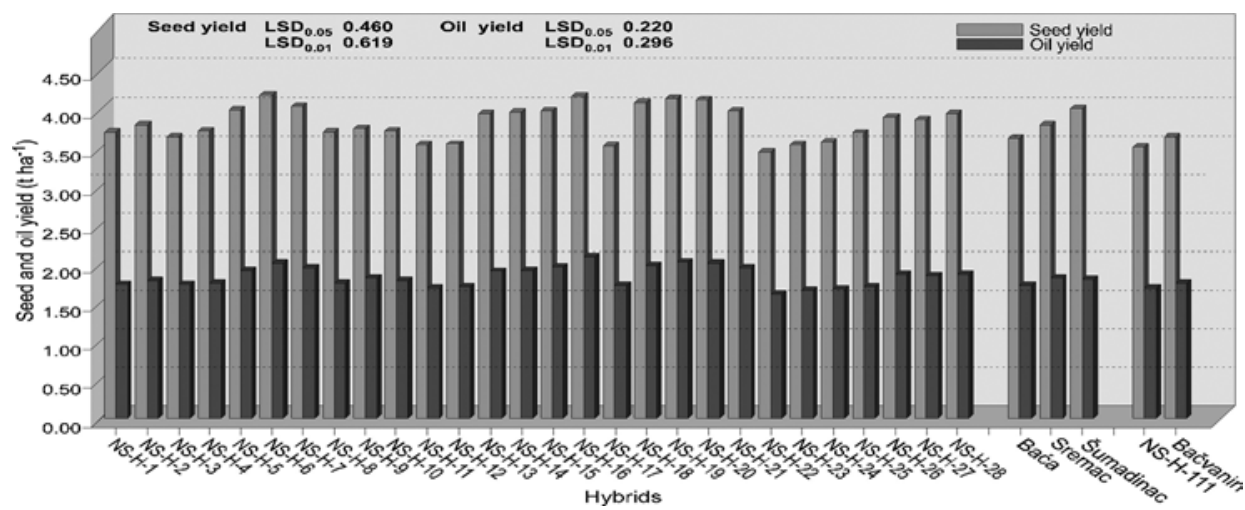

Figure 4: The mean values of morphophysiological traits (seed and oil yield) of the new NS sunflower hybrids, resistant to broomrape race E, tested during 2008/2009 on the location of Rimski Šančevi. 
wild species there is a great variability in populations that mutually differ when it comes to the values of the majority of qualities and traits (Seiler and Gulya, 2004). Here we show that $R f$ inbred lines developed from interspecific population with $H$. deserticola - DES-1474-1 are resistant to broomrape race E and possibly $\mathrm{F}$ and indicate that this population can be used for the production of new resistant sunflower hybrids.

\section{CONCLUSION}

Wild Helianthus species constitute the major reservoir of genes offering resistance to new virulent broomrape races. New NS hybrids resistant to broomrape race $\mathrm{E}$ developed from interspecific population with $\mathrm{H}$. deserticola have achieved higher seed and oil yield in relation to standard hybrids resistant to race $\mathrm{E}$ broomrape Baća, Šumadinac and Bačvanin. It is expected that after recognition by the Serbian Supervising and Testing Institute these hybrids will find their place in the production on the broomrape infected fields.

\section{REFERENCES}

Dedić, B., Lačok, N., Tančić, S., Dušanić, N., Jocić, S., 2009. Current status of broomrape (Orobanche cumana Wallr.) in Serbia. Helia 32(51): 135-140.

Demirci, M., Kaya, Y., 2009. Status of Orobanche cernua Loefl. and weeds in sunflower production in Turkey. Helia 32(51): 153-160.

Christov, M., Batchvarova, R., Hristova-Cherbadzhi, M., 2009. Wild species of Helianthus L.sources of resistance of the parasite Orobanche cumana Wallr. Helia 32(51): 65-74.

Gulya, T.J., Aydin, A., Brothers, M., 1994. Evaluation of broomrape (Orobanche cumana) resistance in sunflower germplasm of the USDA Plant Introduction collection. In: Proc. $16^{\text {th }}$ Sunflower Research Workshop, Fargo, ND, 13-14 January 1994. Natl. Sunflower Assoc., Bismarck, ND., pp. 53-55.

Fernández-Martínez, J.M., Melero-Vara, J.M., Muñoz-Ruz, J., Ruso, J. and Domínguez, J., 2000. Selection of wild and cultivated sunflower for resistance to a new broomrape race that overcomes resistance to $\mathrm{Or}_{5}$ gene. Crop Sci. 40: 550-555.

Fernández-Martínez, J.M., Domínguez, J., Pèrez-Vich, B. and Velasco, L., 2008. Update on breeding for resistance to sunflower broomrape. Helia 31(48): 73-84.

Fick, G.N. and Miller, J.F., 1997. Sunflower Breeding. In: Schneiter, A.A. [ed.], Sunflower Technology and Production. Agron. Monogr. 35, ASA, CSSA, and SSSA, Madison, WI, USA, pp. 395-439.

Hadživuković, S., 1991. Statistical Methods. $2^{\text {nd }}$ Extended edition, Faculty of Agriculture, Novi Sad, (in Serbian).

Hladni, N., Jocić, S., Miklič, V., Saftić-Panković, D., Škorić, D., 2009. Using new Rf inbred lines originating from $H$. deserticola for development of sunflower hybrids resistant to broomrape. Helia 32(51): 81-90.

Jan, C.C., Fernández-Martínez, J.M., Ruso, J., Muñoz-Ruz, J., 2002. Registration of four sunflower germplasms with resistance to Orobanche cumana race F. Crop Sci. 42: 22172218.

Kaya, Y., Demerci, M., Evci, G., 2004. Sunflower (Helianthus annuus L.) breeding in Turkey for broomrape (Orobanche cernua Loeffl.) and herbicide resistance. Helia 27(40): 199210 .

Maširević, S. and Medić-Pap, S., 2009. Broomrape in Serbia from its occurence till today. Helia 32(51): 91-100.

Pacureanu, M.J., Raranciuc, S., Procopovici, E., Sava, E., Nastase, D., 2008. The impact of the new races of broomrape (Orobanche cumana Wallr.) Parasite in sunflower crop in 
Romania. In: Velasco, L. [ed.], Proc $17^{\text {th }}$ Intl. Sunflower Conf., Cordoba, Spain, 8-12 June 2008. Intl. Sunflower Assoc., Paris, France. 1: 225-229.

Ruso, J., Sukno, S., Dominguez-Gimenez, J., Melero-Vara, J.M. and Fernández-Martínez, J.M., 1996. Screening of wild Helianthus species and derived lines for resistance to several populations of Orobanche cernua. Plant Dis. 80: 1165-1169.

Seiler, G.J., 1994. Oil concentration and fatty acid composition of achenes of North American Helianthus (Asteraceae) species. Econ. Bot. 48: 276-279.

Seiler, G.J. and Gulya, T.J., 2004. Exploration for wild Helianthus species in North America: Challenges and opportunities in the search for global treasures. In: Seiler, G.J. [ed.], Proc. $16^{\text {th }}$ Intl. Sunflower Conf., Fargo, ND, USA, 29 August-4 September 2004. Intl. Sunflower Assoc., Paris, France. 1: 43-68.

Seiler, G.J., 2007. Wild annual Helianthus anomalus and H. deserticola for improving oil content and quality in sunflower. Industrial Crops and Products 25: 95-100.

Škorić, D., 1988. Sunflower breeding. Uljarstvo 25: 1-90.

Škorić, D., 2009. Sunflower breeding for resistance to abiotic stresses. Helia 32(50): 1-16.

Virányi, F., 2008. Research progress in sunflower diseases and their managemenet. In: Velasco, L. [ed.], Proc $17^{\text {th }}$ Intl. Sunflower Conf., Cordoba, Spain, 8-12 June 2008. Intl. Sunflower Assoc., Paris, France 1: 1-12. 